\title{
Project Supervision Model of PPP Based on the Effect of the Market Mechanism
}

\author{
Zurong Chen ${ }^{1,23}$ \\ 1.Business School, Hohai University, Nanjing \\ Jiangsu,211100,China;2. Institute of Project \\ Management of Hohai University, Nanjing Jiangsu, \\ 211100 China;3. Sinohydro bureau 16 company limited, \\ Fuzhou, 350003 China \\ E-mail: wangyuting2017@ 163.com \\ Jingchun Feng 1,2,3* \\ 1.Business School, Hohai University, Nanjing \\ Jiangsu,211100,China;2. Jiangsu Provincial \\ Collaborative Innovation Center of World Water Valley \\ and Water ecological civilization, Nanjing \\ Jiangsu,211100 China;3. Institute of \\ Project Management of Hohai University, Nanjing \\ Jiangsu, 211100 China \\ E-mail: feng.jingchun@163.com \\ * Corresponding Author
}

\author{
Huadong Yan ${ }^{1,2}$ \\ 1.Business School, Hohai University, Nanjing \\ Jiangsu,211100,China;2. Institute of Project \\ Management of Hohai University, Nanjing Jiangsu, \\ 211100 China; \\ E-mail: yanhuadong2013@163.com
}

\begin{abstract}
On the analysis of the current situation and problems of the PPP supervision, it can be stated briefly that the PPP project supervision has problems such as the lack of supervision legal system, the unreasonable set of regulators and the vacancy of regulation subjects; different models including the American model-"direct participation"、 the German model-"indirect supervision" and the British and French model-"laissez-faire" are summarized based on analysis of the experience of project supervision in the developed countries; The effect of the market mechanism in the PPP project supervision is discussed, and the PPP project supervision model is classified and discussed according to the effect degree of the market mechanism, furthermore, the supervision model involved by many roles including the government、 market forces and the public is put forward.
\end{abstract}

Keywords- PPP; insurance supervision; project supervision; project connotation; market mechanism

\section{INTRODUCTION}

After the Third Plenary Session of the 18th Central Committee of the Communist Party of China, further defined the market play a decisive role in the allocation of resources. In the background of State Council increase social capital to participate in the construction of infrastructure, PPP model is an important way to further stimulate the vitality of social capital and improve the efficiency of fiscal funds. The ministry of housing put forward some opinions about promoting the construction industry development and reform (to build the city [2014] No. 92), it pointed out the need to accelerate the improvement of modern market system, give full play to the decisive role of the market in the allocation of resources and better play the role of government, correctly handle the relationship between government and market, and the transformation of government functions, deepening the reform of system and mechanism of comprehensive construction. Decentralization, open the market, lay equal stress on both release management and management, to build a unified and open, competitive and orderly, honest and law-abiding, effective supervision national market system construction of; innovation and improvement mechanism the government supervision and management of the quality and safety of the construction market, strengthen process supervision and post supervision, strengthen the linkage between market and construction site, implement the main responsibility of all parties, ensure project quality and safety; at the same time, a number of observations support regional government which lack of regulatory power to explore ways to purchase services, commissioned by the ability of the professional social institutions as auxiliary power of a safety oversight agencies.

In the background of further deepen the reform of economic system, PPP model is an important form of the market play a decisive role in the allocation of resources. Economic reform is focused on comprehensively deepening reforms at the present stage, the core problem is to handle the relationship between government and market, make the market play a decisive role in the allocation of resources, and better play the role of the government. 


\section{REVIEW OF THE RESEARCH ON PPP PROJECT SUPERVISION MODE}

"Supervision" English also called regulation or control, in its essence is the same [1], although the name is not the same, the goal is the same, to solve the problem of market failure and social justice issues [2]. The PPP projects of infrastructure are mostly essentially monopolistic nature, with large-scale investment, asset specificity and information asymmetries and other features [3-5]. World
Bank definition of PPP project supervision is: for private sector participation in infrastructure projects, government or other specific entity directly or indirectly control their decisions or behavior [6]. UK PPP projects has strict laws and regulations, the regulation of the project decisionmaking stage is very strict, when the implementation of the project, the quality control process mainly rely on the market mechanism, the social intermediary role is significant $[7,8]$.

TABLE I. SUPERVISION MODE OF THE UK, SINGAPORE AND AMERICA [9]

\begin{tabular}{|c|c|c|c|}
\hline Country & $\begin{array}{c}\text { Supervision } \\
\text { mode }\end{array}$ & Institutional settings & The main structure \\
\hline Britain & $\begin{array}{l}\text { The vertical } \\
\text { regulation } \\
\text { model }\end{array}$ & $\begin{array}{l}\text { The establishment of a national } \\
\text { regulatory agencies at the national } \\
\text { level, the establishment of a number } \\
\text { of local branches, branches and } \\
\text { between national regulators are } \\
\text { subordinate relationship }\end{array}$ & $\begin{array}{l}\text { Regulatory agencies (such as Water management of } \\
\text { China: Ministry of Environment Water Office, } \\
\text { drinking water supervision committee, office of } \\
\text { Environmental Supervision Bureau) + Horizontal } \\
\text { regulator (such as: Monopolies and Mergers } \\
\text { Commission, the Office of Fair Trading) + Industry } \\
\text { Association of consumers }\end{array}$ \\
\hline U.S.A & $\begin{array}{l}\text { Hierarchical } \\
\text { supervision } \\
\text { mode }\end{array}$ & $\begin{array}{l}\text { Set regulatory agencies at the national } \\
\text { level and local level, but the } \\
\text { regulators of the two levels of no } \\
\text { subordinate relationship }\end{array}$ & $\begin{array}{l}\text { Independent regulatory agencies of American } \\
\text { general by } 5-7 \text { members, can exercise legislative, } \\
\text { executive and judicial powers at the same time }\end{array}$ \\
\hline Singapore & $\begin{array}{l}\text { Single } \\
\text { regulatory } \\
\text { model }\end{array}$ & $\begin{array}{l}\text { Only the establishment of regulatory } \\
\text { agencies at the international level, the } \\
\text { local level do not set the regulators }\end{array}$ & $\begin{array}{c}\text { In the congressional authorization, legal institutions } \\
\text { in a wide range of industries with government } \\
\text { regulation of administrative functions }\end{array}$ \\
\hline
\end{tabular}

ShouKui He and HongYuan Fu (2008) pointed out the existing problems of government regulation of public project: Multiple regulatory, administrative efficiency is not high; regulatory responsibilities are not clear, difficult to protect the interests of investors, target of Investors and regulators is difficult to unity, uncoordinated functions, and put forward the train of thought of the establishment of supervision system [10]. ZhouNi Fang (2010) pointed out that the transformation of government functions in the PPP model, from "fulfill responsibility" into a "supervisory responsibilities"[11]. XiaoSu Ye and YongYan Zhang (2010) emphasized the establishment of a comprehensive and independent regulatory agencies, it participate the supervision of the whole process of project, he advantage is particularly prominent in the construction

Shouqing Wang, Liu Ting (2014) pointed out that the government is responsible person to provide public goods or public service, therefore, on the basis of part of the country on the supervision of PPP project (see Table 2 ), the national level should have PPP legislation and and operation phases of the project, and the analysis of the whole process of the project in different stages of the relevant departments of the regulatory responsibility of [12]. Based on the existing public utilities regulatory practice, Zou Yan (2011) put forward a series of regulation from the perspective of public utilities marketization reform [14]. XiaoChun Lu, YaLing $\mathrm{Du}$ (2014) pointed out that the focus of government regulation is profitability regulation and quality control of private sector [15]. Based on the analysis of the existing regulatory system, Jin Xuan (2014) proposed the establishment of a new regulatory model that has perfect laws and regulations, efficient government regulatory agencies, perfect social supervision, scientific supervision of the government performance evaluation system [16]. PPP guidelines, the establishment of the central and provincial special PPP mechanism, and the establishment of information release mechanism of PPP project[17,18].

TABLE II. COMPARISON OF FOUR COUNTRIES (REGIONS) PPP PROJECT SUPERVISION SYSTEM

\begin{tabular}{|c|c|c|c|c|}
\hline $\begin{array}{l}\text { Countries } \\
\text { (regions) }\end{array}$ & Australia & Hongkong & South Africa & Britain \\
\hline PPP department & $\begin{array}{l}\text { Ministry of national } \\
\text { infrastructure/ Local } \\
\text { finance }\end{array}$ & $\begin{array}{c}\text { Secretary for } \\
\text { Home Affairs the } \\
\text { efficiency unit }\end{array}$ & $\begin{array}{l}\text { National Treasury } \\
\text { PPP group/local } \\
\text { authorities }\end{array}$ & $\begin{array}{c}\text { Finance/national audit office and the } \\
\text { public utilities Commission }\end{array}$ \\
\hline $\begin{array}{l}\text { Organization } \\
\text { types }\end{array}$ & $\begin{array}{c}\text { Central } \\
\text { Government/local } \\
\text { authorities }\end{array}$ & $\begin{array}{l}\text { Central project } \\
\text { group/local }\end{array}$ & $\begin{array}{l}\text { Central project } \\
\text { group/local }\end{array}$ & Central Department/Agency \\
\hline Policy properties & $\begin{array}{l}\text { Central policy, guidance } \\
\text { document and special } \\
\text { requirements }\end{array}$ & $\begin{array}{l}\text { Central policy and } \\
\text { guidance } \\
\text { documents }\end{array}$ & $\begin{array}{l}\text { Guidance } \\
\text { documents }\end{array}$ & $\begin{array}{l}\text { Central policy and guidance } \\
\text { documents }\end{array}$ \\
\hline File attributes & $\begin{array}{l}\text { Model of technical } \\
\text { documentation, case } \\
\text { studies, FAQ }\end{array}$ & $\begin{array}{l}\text { Technical } \\
\text { documentation, } \\
\text { case model }\end{array}$ & Case model & $\begin{array}{l}\text { Technical documentation, case } \\
\text { model, Excel models }\end{array}$ \\
\hline
\end{tabular}




\section{REGULATORY STATUS AND PROBLEM ANALYSIS} OF PPP PROJECTS

\section{A. PPP project lack of supervision legal system}

\section{1) The existing legislation ranks low}

Most of the existing legislation for PPP projects is administrative rules and local legislation, so there is lack of legal hierarchy of legal documents. According to statistics,11 laws are related to PPP projects in legal aspects, 4 sets of administrative regulations are associated with PPP projects, 11 ministry regulations are associated with PPP projects, 28 local legislation are in connection with PPP projects. From the statistic point of view, most the existing PPP legislation are administrative rules and local legislation and the legislative types and quantity of these are abundant, but the rank is lower, the legal effect is not high, the PPP legislation at the NPC level is still vacant.

\section{2) The contents of the provisions are lack of} maneuverability

The existing PPP legislation are mostly administrative rules and local legislation, the content of these legislation are broad and are lack of maneuverability, and the constraint is not strong, which leads to lack of relevant laws, regulations and regulatory policies to support PPP projects.

As for the problem that provisions of the regulatory body, object, scope, means are not specific and clear enough, and the problem like "who will regulate, what will be supervised, how to supervise" and other issues are not yet clear, which contributes to poor co-ordination, multiregulatory, regulatory conflicts and so on.

\section{3) Application conflict of the existing laws}

In the absence of legal aspects of PPP legislation, choose to use different laws when it came to the conflict of using which one, now the primary problem which is urgently needed to clear is that PPP project is applicable to "People's Republic of China Bidding Law" or "People's Republic of China Government Procurement Law". Applicable conflict exists between these two laws since they are published. While the current PPP project is clearly defined ,the problem is more difficult.

In addition, conflict on the application of the law also appear when enterprise or project company obtain the right of franchise.

Another example is how the project company gets the land use right in PPP projects, according to the current laws, commercial land-use rights must be obtained through bidding, auction and listing, the "tender auction listing to sell state-owned land use right regulation" and "tender auction listing to sell state-owned land use rights norms" prescribed procedures and methods must be strictly enforced. Acquisition of franchise cannot guarantee the project company to obtain the land use right. How to make franchisee's bidding, and land-bidding auction listing program come to unity? These applicable laws conflict encountered in the practices are endemic problems of PPP projects.

There are many similar problems, such as if the project company have a project asset, double taxation in PPP projects ,supervision issues in PPP projects and financial capital injection methods are all need to be solved.

\section{B. Set of PPP regulators are unreasonable}

1) The absence of PPP Center in national level

At present, the domestic construction supervision of the project mainly involves development and reform, finance, state-owned and industry sectors, the responsibilities are basically clear. But the PPP project involves the applicable law selection and franchising, cross-sectorial inter-regional projects are diverse, which break the old regulatory status of the project. As a result, the existing regulatory system and the project supervision model will no longer meet the PPP projects, in order to carry out effective supervision of the PPP project, supervision system and supervision model must be redesigned.

Seen from the PPP center established in foreign countries, common functions of PPP center are: policy study, standard-setting, project selection, expert support, project appraisal, financial support and statistical analysis. Combined with China's current administrative systems, there are two ideas of setting PPP center at the national level, one idea is to establish inter-ministerial PPP administration. Certainly, this is the most desirable, but does not conform to the direction of the reform of our institutions. The other idea is to adjust and optimize the functions of the existing ministries and set up a PPP management institute in the administration.

2) Department functions are not explicitly implemented

Under the current administrative system, there is crossover when defining the powers and responsibilities among the various government departments as well as the lower and higher levels of government. Furthermore, there is no clear division of responsibilities in supervision of construction projects. Development and Reform Commission, Ministry of Finance and various industry department have certain rights of supervision of all urban infrastructure, but overlapping functions of regulatory authorities are serious. This will lead to finger-pointing among regulators, thereby reducing the efficiency of supervision, even leaving regulatory loopholes, the burden on corporate projects is also increased objectively.

The current PPP model as domestic new construction process of urbanization main push model, an important reason of the loss of supervision is that the existing regulatory system model is no longer adapted to the PPP model, Development and Reform Commission, Ministry of Finance, as well as the sectorial ministries function is not clear, the regulatory division is fuzzy. For instance, Ministry of Finance official website issued a document that the government and the Ministry of Finance set up social capital cooperation (PPP) Work Leading Group, but in infrastructure utilities franchise legislation, the DRC is the competent authority, then who is the regulatory responsibility sector of PPP projects? In fact the problems that often encounter is that no sector regulators is to supervise the project, pr all departments are to supervise the project. It has occurred from time to time, and that leads investors not to know what to do.

\section{Absence of PPP regulation body}

Domestic project supervision is still dominated by government regulation, and weakened social intermediary market oversight and public scrutiny of these two 
regulatory power that cannot be ignored. Under PPP model, the government as a provider of public goods and public services, entrusted to the private sector in the construction of public projects through the development of appropriate rules for the whole investment project construction and operation supervision, aimed to provide the public with better efficiency quality public services. However, in PPP mode, investors are mainly pursuing economic interests, while the government is pursuing social welfare, the two are different, in the absence of government regulation in place, the investor due to cost considerations is likely to affect service and product quality. Because of the lack of public participation in regulation on behalf of the public interest, the lack of response channel for users to express their interests, such as quality of infrastructure service and price,, so the public interest is likely threatened under the circumstance that the protection is absent. If there is the lack of regulation of public participation, there is no perfect social supervision system, it can not guarantee quality of service entities of PPP projects, and thus can not meet the public interest.

\section{EXPERIENCE REFERENCE OF PROJECT SUPERVISION IN DEVELOPED COUNTRIES}

At present, developed countries don't intervene the acceptance check of the construction project directly, but in varying degrees, they check the access, quality, safety, price and environmental impacts of the project running through certain forms. Broadly speaking, this checking behavior is essentially the government supervision behavior. According to whether the government director department are directly involved in the check of the project completion quality, safety, and the extent of participation in check. It reduces government supervision behavior to the three modes: direct participation mode, indirect supervision mode and no supervision mode[19].

\section{A. "Direct participation" pattern-United States patterns}

The organization of direct supervision and management. US construction management system is mature, the role of government in the construction activity is very positive. The US engineering construction management system can be broadly divided into federal and state local management. Federal regulators mainly includes interior bureau of reclamation, the federal energy commission. Among them, the Bureau of reclamation is mainly responsible for the construction and management of large scale projects and the federal project, the Federal Energy Commission is the department responsible for the licensing of small and private engineering. Army engineers and the Tennessee valley authority is established on the basis of congressional legislation which has the function of the enterprise construction and management mechanism, they both have the function of government regulation. State and local construction management department also have set.

United States Government regulatory content. The relative law of US expressly provide that the Government direct supervise projects quality, the main form is that the construction director department of US sends or delegates personnel to check. Government inspectors are divided into two types: one is the Government's own inspectors, and another is temporarily employed by the government or require owners to hire outside inspectors, is a Government-approved professional. The contractor shall cooperate with the government's supervision and inspection work. Check the official supervisory duties are legally clear and detailed provisions. If irregularities are found in the inspection, inspectors can impose penalties, improvement agreement signed to deal, fines amount increases with the increasing of the fine number. For the environmental impact after the project completion, United States authorities will direct review, assess, in accordance with the relevant legislative provisions.

\section{B. $\quad$ "Indirect supervision" mode-Germany models}

The organization of indirect supervision and management. Germany government supervise and manage the project quality, safety, mainly by the government director department authorize, The quality supervision and management company formed by the Nationally recognized engineers supervise and inspect the Structure construction, includes project's quality, public safety, fire prevention, environmental protection and so on mandatory. It ensures the authority, impartiality and professionalism of the supervision. Government only supervise and inspect the intelligence and behavior of the quality inspection and supervisory engineers, not to supervise and inspect the specific projects, which will strengthen the government's macro-control of the work quality.

Germany government regulatory content. The focus of the inspection and supervision of the Germany government is to ensure the safety of the engineering structure. According to the Germany law, the federal Government supervise the quality of the project. The Germany construction has a special ministry responsible for engineering quality supervision and management, but only legislates on the building in principle. For construction projects, because they relate to coordination problems between the States, harmonizing legislation and management required by the Federal Government. Construction quality inspection and supervision costs paid by the employer to the administrative departments, the Government transfer them to the commissioned quality examination and supervision company, the owners don't direct give them to quality examination and supervision company, it avoids the employment relationship between the quality examination supervision company and the owners. Germany quality examination and supervision corporations to be under the jurisdiction of the State quality inspection and supervisory tasks, but according to their job performance, abilities and social prestige, uniform distribution by the competent Department of the Government, it avoids alone quality examination and supervision company's monopolistic practices within the same region.

\section{C. "Laissez-faire" model-France mode}

France government supervision mode In France, there is no special administrative departments. Construction management function is primarily completed by public transport, Ministry of transport and tourism. But the departments don't intervene construction process of the construction project directly, but use laws and regulations and economic means to supervise engineering quality including completion inspection and acceptance activity. 
France has a complete technical legislation, such as "the NF" (France) and "DTUFF" codes (France), providing the necessary basis for quality inspection, quality accreditation. These two technical regulations are mandatory for government investment construction of public works, but not mandatory for private investment in civil engineering ((except public security). But when it comes to insurance, insurance companies will ask all units participating in project activities $s$ to insure their works must comply with "NF" and "DTU" requirement. France introduced a typical compulsory construction insurance system, insurance companies ask each project in the construction process must entrust a quality inspection company for quality inspection, the quality inspection of the company shall not be involved in any commercial activity other than the quality in the domestic to keep it objective and fair position of third parties.

These three models are the main mode foreign construction engineering supervision. At present, the main mode is direct government supervision of construction projects, the task of government regulation is onerous and wide range of large, inefficient, and difficult for professional and efficient regulation. In view of the Government role and the function of government has continuity in the construction phase and operation phase of infrastructure PPP projects, more attention should be paid to the market regulation in regulatory activities. Therefore, learn from the successful experience of foreign construction engineering supervision to provide reference for building government supervision mode in the field of infrastructure PPP projects.

\section{REGULATORY MECHANISM OF MARKET ANALYSIS OF PPP PROJECTS}

\section{A. The separation, a clear government role localization}

The effective implementation and operation of the ppp project need to clear and perfect government responsibility system, raise the level of market supervision, strengthen social management and public service functions. Adhering to the separation of government and enterprise, government and capital and politics separate, adjusting and standardizing the government management, reducing the government's intervention on the microscopic economic activities, fully performing the government regulatory role. On this basis, define the property rights of PPP projects, clear the management main body, develop specialized regulatory agencies, make the professional people do professional things, effectively improve the regulation efficiency of PPP projects.

\section{B. Introduce the market mechanism, the implementation of ppp projects market supervision}

In regulatory practice of PPP projects, it can be directed through open tenders, commissioned by the government, invited to bid form will be transmitted by the public administration services themselves to market to fulfill by relevant enterprises to implement PPP projects regulatory tasks. Now there are two kinds of market mechanism of supervision model for reference, firstly, supervision of insurance and guarantees, through the floating, guarantee and insurance rate regulatory activities for ppp projects, as the guarantee and insurance rates to be determined by considering the reputation and performance of the enterprise, in order to obtain preferential treatment, guarantee and insurance rates, enterprises must strengthen management to improve the reputation of the project, the accumulation of good performance; secondly, government purchases of ppp project supervision services, namely, the government, through appropriate choice of ppp projects specialized intermediary supervision, use professional ability and introduction of effective regulation of ppp projects. Innovative public functions performed by government purchase a monitoring service is a new way, conducive to the introduction of competition mechanism to provide subject and provide multiple ways.

\section{Meets the requirements of small government and social reform in china}

"small government, big society" is a long-term task for chinese government reform. Government intervention directly to project too much will inevitably lead to government departments, which is not in line with china's construction of "small government, big society" goals. The reason that "small government, big society" is put forward is to weaken the government's functions in social activities, to give full play the regulation ability of the market and social organizations. When government power is small, relatively the social power that is a major. Government does not interfere what we can solve with the "big society", businesses, citizens and social organizations to play selfmanagement. Therefore, the government's indirect supervision mode and regardless of the pattern for construction of PPP projects, such as government regulation is of great reference value, go with "small government, big society" trend and developed experience in project supervision, particularly in government indirect regulatory approach is more in line with China's state supervision the actual PPP project.

\section{REGULATORY MECHANISM OF MARKET SUPERVISION MODE ANALYSIS OF PPP PROJECTS}

In order to ensure the success of PPP projects, PPP projects need to build a sound regulatory approach to achieve effective supervision of the PPP project. With the accelerated marketing process, China is gradually trying to reform of the Government supervisory systems, PPP projects so far as monitoring is concerned, the lack of related laws and regulations, the regulatory system is not yet perfect, poorly regulated or are likely to cause losses. Development process of PPP is short, there are shadows of the planned economy of the government regulation pattern in China, excessive direct government intervention, it is difficult to fully apply the financing and construction of the marketization of public-private cooperation model. How to adjust the relation between Government and market mechanisms, make government regulation cannot function or transfer of inadequate project monitoring functions performed well by the market mechanism, through the market mechanism to undertake the transformation of government functions and transfer functions, built based on the Government Regulation, market mechanism for important PPP projects supervision is necessary. 


\section{A. Full play the decisive role of the market}

Insurance, assurance and guarantee supervision belongs to the government's indirect supervision mode, France is a typical implementation of compulsory construction insurance system of the country. The construction duties and insurance in France stressed, all construction activities in all units, must apply to the insurance company. Implementation of compulsory construction insurance system, the contractor must be insured from the insurance company, and the insurance rates is in accordance with the level of risk, the contractor's corporate reputation, quality check of depth, considering General offers to pay insurance premium equivalent to the total project cost $1.5 \%$ 4\%[19].

Importing insurance, warranties and guarantees these three modes of government indirect control, it similar to auto insurance, participation all parties need to pay premiums. According to the degree of the project's risk ,the contractor's reputation and the quality check of depth, The contractor 's guarantee and insurance of PPP project should take the insurance at the rate of total cost of project. Floating charge premium rates is good to improve the PPP project participant awareness of project management, if items is out of control, such as quality issues, financing credit problems and so on, the businesses involved in the PPP project will have to pay higher guarantees and insurance rates. As the guarantee and insurance rates which are determined considered the reputation and performance of the contractor, in order to obtain preferential treatment, guarantee and insurance rates, the contractor will be accumulated through enhanced quality control and improving the reputation, good performance, thus facilitating supervision and management to ensure the sound development of PPP projects. Mandatory guarantee and insurance systems can enhance the PPP project the main parties involved in swing, but top-level design is not perfect. The main function of the role of government is to maintain market fairness and to configure the balance of market resources. The more time of deepening economic reform, the more need to be emphasized and implementation of the regulatory functions of government. In the transitional period. All regulatory power should be integrated to ensure the supervision effect so that to provide for the smooth implementation of the government's regulatory

In the transitional period, the supervision mode of PPP projects is a combination of direct supervision and indirect supervision. On the basis of the government macro-supervision of PPP projects, full play to the role of market mechanisms in supervision should be given. Meanwhile the insurance company's insurance regulatory power should continue to foster and encourage its development. Social agency as a professional project management strength with projects to control and monitor activity. The regulatory approach in this completely using market mechanisms is a trend for project monitoring in the future.

\section{B. Basically make the decisive role of the market}

From the project supervision experience of developed countries, learn about the intermediary institutions in foreign countries play more role than that in domestic. The government should allow agencies to achieve professional people to do professional things, to play the decisive role of market mechanism.

In General, the PPP project cycle is longer, development process, documents and performance of the contract and its difficulties in project implementation, therefore, government departments should delegate agencies and professional supervision such as engineering consulting firms involved in PPP projects. Judging from the experience in the implementation of PPP projects, the professionalism and effectiveness of regulation, directly affect the efficiency and success of implementation of a PPP project.

Intermediaries as a market force, strong professional knowledge, practical experience, so choose the right social media regulation of PPP projects. In addition, from the perspective of little government and big social, fully play the role of the market, introduce social intermediary, as market operation project regulatory units, bear PPP project investment construction and operations full process of regulatory task, provides professional of run management and the maintenance service, and the government is bear financial support PPP project of macro regulatory content, thus as achieved on PPP project of effective regulatory.

\section{Supervision mode of PPP projects in transitional period}

During the gradual deepening of the market economy in transitional period. PPP projects currently are in full safeguards of PPP projects. The degree direct supervision of government intervention in the foreign government is less than that of the national government. Domestic regulation is wide and large and this will make the government is short of coverage. While implementing regulation, the role of market mechanisms, warranties and insurance intermediaries and other market forces and project supervision should be introduced.

professional ability, high supervision efficiency, which are important role of market mechanisms in the form of project supervision. Besides , PPP projects involve many community stakeholders. As part of the urgent need to introduce public supervision indispensable PPP project, thus as shown in Fig.1. For supervision, PPP projects should be form the government, market forces and multiple supervision mode of public participation. 


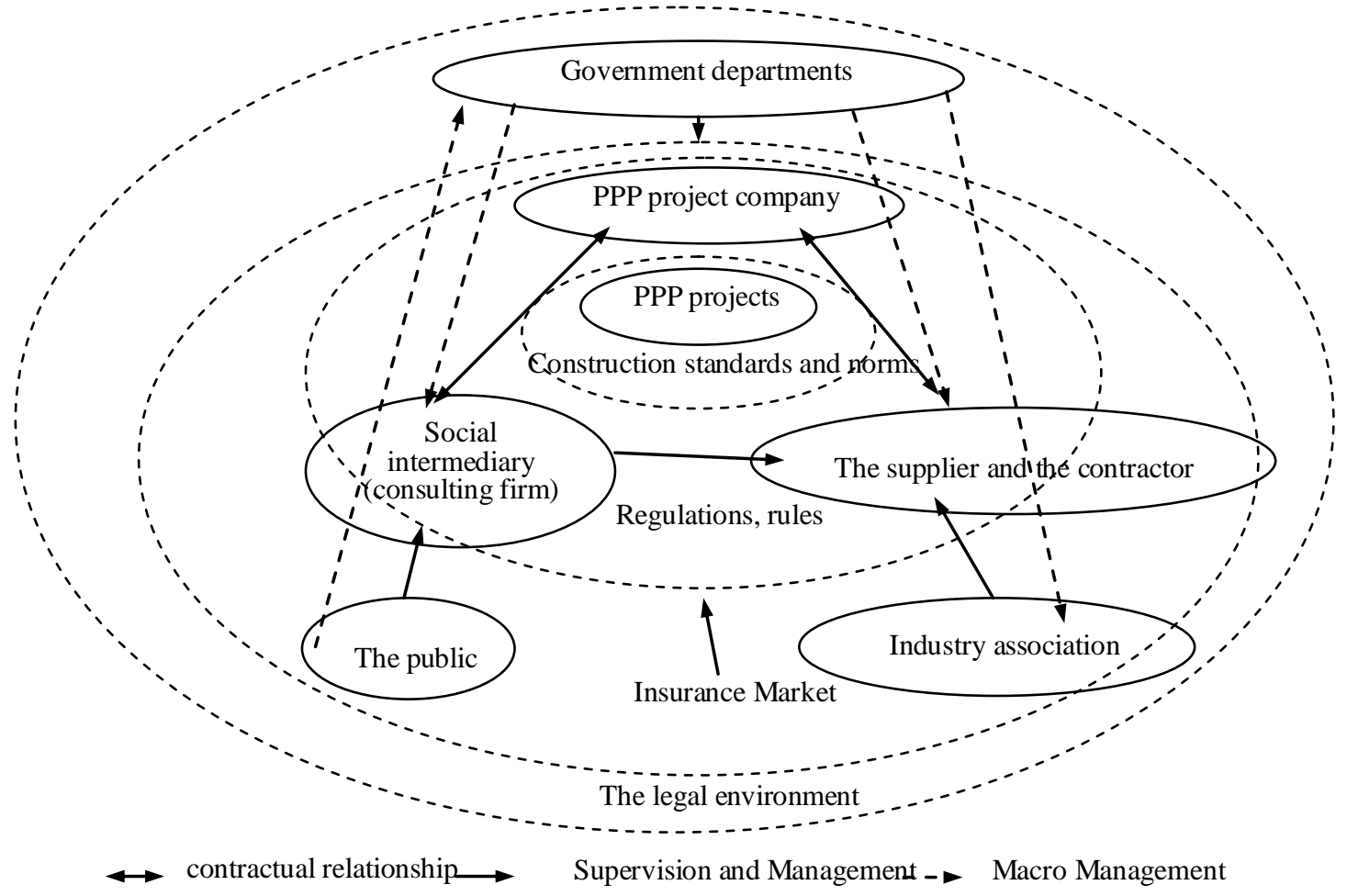

Figure 1. Supervision mode of PPP project in transitional period

\section{CONCLUSION}

(1) Currently legal supervision system of PPP projects is not perfect and the existing legislation hierarchy is low. Conflicts of PPP projects in existing legal system supervision, unreasonable regulatory agencies and regulatory body vacancy lead directly to the lack of government regulation of PPP projects and the lack of effective supervision for the whole life cycle of PPP projects.

(2) Domestic regulation is wide and of large capacity, which makes government does not have the ability to lead the implementation of effective supervision of construction projects. From the experience of project supervision in developed countries, the degree of government intervention in foreign direct supervision less than that of the national government level of intervention and has higher efficiency of supervision and learn supervision experience from foreign countries. In the design of Supervision model in PPP projects The role of market mechanism in the project supervision should be fully considered.

(3) Give full play to the role of market mechanism in the project supervision, it may derived from warranties, guarantees, insurance, and government purchase of social services and other intermediary regulatory supervision model PPP projects. Insurance regulation is the inevitable trend of development of the project supervision. At present, specific conditions and the binding characteristics of PPP projects, transitional supervision model in PPP projects can be used, namely the multi-Supervision model including government, market forces and public participation .

\section{ACKNOWLEDGMENT}

【1】 This work was supported by The National Social Science Fund (Key Project of the 2012, Grant No. 14AZD024):The innovation of mechanism of Public Private Partnership under the financial support in the field of infrastructure; 【2】 The financial support from the China Postdoctoral Science Foundation with Grant No. 2014M551498; 【 3 】 This work was supported by the Fundamental Research Funds for the Central Universities (2013/B14020090): The decision mechanism of Public Private Partnership under the financial support in the field of large-scale infrastructure.

\section{REFERENCES}

[1] Junhao Wang. Control Principles of Economics [M]. Beijing: Higher Education Press, 2007.

[2] Guasch J L H R W. The costs and benefits of regulation: Implications for developing countries[J]. The World Bank Research Observer. 1999, 14(1): 137-158.

[3] Xueqing Wang. Study on Government Control in monopoly industries [J]. Management World. 2003(08): 63-73.

[4] Marques R C B S V. Revisiting the strengths and limitations of regulatory contracts in infrastructure industries[J]. Journal of Infrastructure Systems. 2010, 16(4): 334-342.

[5] Harris C. Private Participation in Infrastructure in Developing Countries: Trends, Impacts and Policy Lessons[M]. Washington: World Bank Publications, 2003.

[6] Brown A C, Stern J, Tenenbaum B W. Handbook for Evaluating Infrastructure Regulatory Systems[M]. The World Bank, 2006.

[7] Development and Reform Commission inspectors system of government investment to the UK regulatory system training group, Zhongbao Fu, Kangmin ZhangFu Zhong Bao, Zhang Kangmin, etc.. Features and analysis of the British Government Investment Project Supervision [J]. Chinese investment. 2010(05): 104-105.

[8] Development and Reform Commission inspectors system of government investment to the UK regulatory system training 
group, Zhongbao Fu, Kangmin ZhangFu Zhong Bao, Zhang Kangmin, etc. Enlightenment of the British Government Investment Project Supervision System [J]. Chinese investment.. 2010(06): 106-107.

[9] Xiaochun Lu,Yaling Du,Kai Yue.etc. On the Supervision of cooperation government and social capital (PPP) projects [J]. Tianjin economy. 2014(08): 56-58.

[10] Shoukui He, Hongyuan Fu Public project supervision system of public-private partnerships and regulatory approach [J]. Construction Industry. 2008(12): 75-78.

[11] Zhouni Fang. On the supervision of PPP project is based on the reputation of the model $[\mathrm{J}]$. Friends of Accounting (in Xunkan). 2010(01): 27-28.

[12]Xiaosu Ye, Yongyang Zhang, Xiaopeng Li. Government regulatory mechanisms of PPP project design $[\mathrm{J}]$. Construction Industry. 2010(04): 93-96.
[13] Yan Zo. Public utilities market strategic restructuring and regulatory instruments [J]. Reform. 2011(04): 123-129.

[14] Xiaochun Lu,Yaling Du,Kai Yue.etc.. On the Supervision of cooperation government and social capital [J]. Tianjin economy.. 2014(08): 56-58

[15] Xuanxuan Jin. Innovation of Public Utilities in the regulatory system under the public-private partnership system $[\mathrm{J}]$. Special Zone Economy. 2014(08): 53-55.

[16] Shuqing Wang,Ting Liu.PPP project supervision: domestic and international experiences and policy recommendations $[\mathrm{J}]$.. Local Fiscal Studies. 2014(09): 7-12.

[17] Shuqing Wang,Ting Liu.. Recommendations for strengthening supervision of PPP projects [J]. Economic Research 2014(60): 1415.

[18] Bosen He. International practice project management [M]. Beijing: China Building Industry Press, 2007: 360-363. 